\title{
O Papel da Música no Processo (Re)Criativo Cinematográfico
}

\author{
The Music Role in the Cinema Recreation Process
}

\section{Eva Cristina Francisco*}

Resumo: Os efeitos de sentido engendrados pelos recursos musicais trazem e instigam emoção, ideias, sentimentos. A música tem o poder de embalar, tocar, envolver, contar histórias. Nesse sentido, o presente trabalho objetiva mostrar a importância da atuação da música no cinema para a recriação fílmica. Dizemos recriação por se tratar de uma adaptação de uma obra literária para um texto verbo-audiovisual. $O$ estudo trata do transmutar de formas do romance O Primo Basilio, do escritor português Eça de Queirós (1878), para o filme produzido e dirigido por Daniel Filho (2007). Por meio da Teoria da Tradução, da Metodologia da Crítica Genética, bem como a análise das músicas utilizadas para a filmagem final do longa-metragem, é possível perceber a importância da atuação da música na obra cinematográfica no que diz respeito a contar histórias, sintetizar acontecimentos, contribuir com a impressão de veracidade, subsidiar a fidedignidade, reconstruir o enredo, enfim, efetivar a recriação cinematográfica.

Palavras-chave: Música. Crítica Genética. Recriação cinematográfica.

Abstract: The meaning effects engendered by musical resources bring and instigate emotion, ideas, feelings. The music has the power of lulling, touching, envolving, telling histories. Thus, this paper aims to show the importance of music role in the cinema for the movie recreation. We can say recreation because this paper studies the adaptation from a literary text to a

\footnotetext{
* Doutora em Estudos da Linguagem pela Universidade Estadual de Londrina (UEL). Professora no Instituto Federal de São Paulo - Câmpus Avaré. Contato: evacf1166@hotmail.com.
} 
cinematographic text. This research brings the transmutation of forms in the novel Primo Basilio by the Portuguese writer Eça de Queirós (1878) to the movie produced and directed by Daniel Filho (2007). Through the Translation Teory, the Genetic Criticism Methodology, as well as the analysis of the music used for the final shooting of the movie in study, it is possible to notice the music role importance in the cinema in regard to telling histories, synthesizing happenings, contributing with the truth impression, assisting the fidelity, reconstructing the plot, ultimately, actualizing the cinema recreation. Keywords: Music. Genetic Criticism. Cinema recreativon.

\section{Introdução}

Os estudos da linguagem permitem a investigação e análise de textos dos mais diversos gêneros. A linguagem, em sentido lato, abrange as formas de comunicação de todo e qualquer jaez. Nesse sentido, trabalhamos com a linguagem da música no cinema como auxiliar no processo de recriação de uma obra verbo-audiovisual, cujo texto original trata de uma obra clássica da literatura. Partindo de um texto homogêneo, a transmutação resulta em um gênero de texto sincrético e para isso é necessária a tradução intersemiótica dos signos.

O intuito desse estudo é mostrar que a trilha sonora, especialmente a música, pode compor os elementos constituintes do cinema e ser substancial no processo de transformação de uma obra literária para uma audiovisual. O cinema, como arte coletiva, abrange diversos componentes para a sua realização e para um bom resultado final. Para tanto, a sétima arte conta com um trabalho simultâneo de diversos artistas, bem como o apoio da tecnologia. Além do diretor, produtor e atores/atrizes, o texto cinematográfico precisa da colaboração do papel da câmera, do figurino, da maquiagem e, dentre muitos outros elementos, do trabalho com a sonoplastia.

$\mathrm{Na}$ investigação proposta são colocadas observações que desvelam o quão importante pode ser a escolha de uma boa música para um filme. O quanto uma letra musical e sua melodia podem contribuir para contar a história, o enredo. Ademais, esse estudo revela que, para que certa música chegasse às filmagens, houve um processo de escolhas, renúncias, idas e vindas por parte da direção/produção. 
A transmutação de formas exige um processo de análise e síntese, acréscimos e supressões, conjunções, disjunções e transcodificações. Assim, por meio da metodologia dos estudos sobre a gênese da criação e com base na teoria da tradução, é possível percorrer alguns dos passos dados durante o trabalho do cinema como arte coletiva. Num primeiro momento, vale mostrar que não só a música, propriamente dita, compõe os sons expostos em um filme e que ela faz parte da trilha sonora responsável pela emoção, motivação, expectativa do público. Logo em seguida, mostramos uma análise e reflexões sobre as duas músicas utilizadas em dois grandes momentos do filme que ajudaram a relatar a história de forma mais instigante, emotiva e eficaz. Num terceiro momento, revelamos escolhas prévias de outras músicas que estariam na realização de Primo Basílio. Tal revelação só foi possível porque tivemos acesso ao roteiro escrito - material físico inédito fornecido pela assessoria do diretor do filme.

Muitas descobertas e reflexões podem ser feitas quando se trata da atuação da música no cinema. Além de subsidiar no processo de criação fílmica, mesmo quando se trata de uma adaptação provinda de um romance, a música tem o poder de instigar, emocionar, trazer maior agradabilidade ao público, além da profundidade de campo ou impressão de veracidade, imprescindíveis para uma obra cinematográfica bem-sucedida.

\section{Trilha Sonora}

As pesquisas sobre a gênese da criação e tradução abarcam os processos comunicativos em sentido mais amplo. As artes em geral são investigadas por meio de seus elementos que formam um todo. $\mathrm{O}$ estudo da gênese de uma obra possibilita o conhecimento do antes e a transformação da obra na construção de um caminho que conduz ao entendimento do produto final e, muitas vezes, de seu(s) autor(es). Nesse contexto está a trilha sonora como um dos elementos constituintes do cinema e auxiliadora da tradução. Ela pode atuar como linguagem dentro de um filme. Tem o poder de embalar, tocar, sensibilizar o espectador, de forma que este se envolva com a trama, muitas vezes como se estivesse vivendo a história com os personagens. Possui sua própria forma de comunicar que se inter-relaciona com o contexto no qual ela é aplicada. Na transmutação de formas, o criador 
consegue utilizar a trilha sonora para dizer além do que está sendo mostrado no enredo ou na tela, pois:

Traduz-se aquilo que toca, que sensibiliza, que provoca; [...] Buscam-se traduzir as semelhanças não explícitas no original, instalando um desequilíbrio entre o estabelecido e o convencional e o resultado da operação criativa. Como se pode perceber, tradução e criação se interpenetram (PANICHI; CONTANI, 2003, p. 143).

De modo geral, classificamos a música de um filme de trilha sonora. Porém, segundo Berchmans (2006, p. 19), o real significado deste termo origina-se do inglês da palavra soundtrack que, tecnicamente, diz respeito a todo um grupo sonoro de um filme que abarca, além da música propriamente dita, todos os outros sons e até mesmo os diálogos. Mas, na prática, a expressão "trilha sonora" é aceitável e geralmente se refere à coletânea de músicas que compõem um filme, uma novela, uma minissérie. Porém, ao nos depararmos com o termo trilha sonora não significa que estamos diante apenas da música (letra e melodia) do filme. No universo do cinema, há diversos elementos sônicos que ampliam as possibilidades criativas de realização fílmica. Tudo é audível. Segundo Chion (2011, p 30-35), os componentes da trilha sonora que subsidiam o processo criativo no cinema são: a voz, os ruídos, o silêncio e a música. A especificidade de cada projeto fílmico é que define a qualidade e a força narrativa de cada elemento sonoro vinculado à imagem. Para a música dedicamos uma atenção especial, já que as músicas tocadas em pontos marcantes do filme Primo Basílio, além da força expressiva engendrada, atuam também na narratividade da história e, consequentemente, na transmutação de formas.

A voz é desempenhada pelo texto falado, verbal. Apresenta-se nos diálogos e no voice over (quando há narração, além dos diálogos). Esse suporte do cinema, ou seja, o diálogo, que estabelece a fala dos personagens, substancialmente em primeiro plano sonoro, é originado do teatro e integra à voz uma função dramática, emotiva, afetiva, psicológica e informativa. "A VOZ passa a desempenhar papel fundamental na estrutura da narrativa, possuindo a mesma relevância que a figura humana desempenha na imagem" (SOUZA, 2010, p. 52). 
Os ruídos são os sons que não são musicais nem linguísticos. $\mathrm{Na}$ categoria dos ruídos eles se subdividem em: ruídos de ambiente, que se referem aos sons da natureza que fazem parte da cena, tais como trovões e sons de animais; ruídos de efeitos, que procedem de objetos participantes do cenário do filme, como buzinas, carros e explosões e os ruídos de sala que se referem a movimentos e ações dos personagens da cena, tais como passos, socos, o som de arrastar um móvel, entre outros.

O silêncio, também componente da trilha sonora, atua como elemento importante na narrativa fílmica. O silêncio se manifesta, muitas vezes, com o intuito de instigar o espectador que tentará prever, predizer a ação sequente ao silêncio estabelecido na cena a que assiste. "Quando o silêncio precede o som, a antecipação nervosa o torna mais vibrante" (SCHAFER, 2001, p. 355). O silêncio funciona como uma maneira de ressaltar para o espectador, situações essenciais para a compreensão que o diretor almejou para a narrativa. Quando não se ouve certos sons, que hipoteticamente complementariam a imagem, o espectador encontra-se vinculado ao estado de espírito do personagem que conduz a cena. $\mathrm{O}$ silêncio, intercalado entre uma ação e outra, gera a concentração do espectador em relação a tais ações. Além disso, este elemento pode possuir um valor sintático no universo audiovisual. Aplicado como elemento desprendedor entre dois eventos sonoros indicando que "em seguida, começará algo completamente diferente" (SHUN, 2008, p. 183); um valor autêntico, de acordo com a narrativa e, um valor dramático com o intuito de gerar efeitos emocionais tais como suspense, perigo, tensão, medo, solidão, reflexão. Enfim, “o silêncio no cinema tem valor de uma ausência de sons reais; é pois, um objeto acústico exatamente como os sons da fala, a tosse ou os rumores da rua" (JAKOBSON, 2007, p. 157).

Quanto à música (no sentido letra/melodia), podemos dizer que ela integra um dos mais poderosos componentes da dramaticidade da produção fílmica e ocupa uma posição privilegiada na trilha sonora cinematográfica. A música como arte percorre por um sistema de criação compondo as demais artes como o teatro, por exemplo. Sendo o meio da produção musical muito amplo, é importante que as capacidades expressivas da musicalidade sejam respeitadas e visualizadas. Muitas vezes, é a música que constitui a atmosfera emotiva da trama. Por meio dos recursos sonoros provenientes da tecnologia, como também das palavras e dizeres significativos que compõem uma música, 
o espectador experimenta um grau de introspecção que pode levá-lo a se inserir no mundo da diegese aos seus olhos apresentada. Nesse contexto, a música exprime diretamente a sua participação na emoção da cena, dando o ritmo, o tom e o fraseado adaptados, "isto evidentemente em função dos códigos culturais da tristeza, da alegria, da emoção e do movimento" (CHION, 2011, p. 14).

A obra cinematográfica e a música são expressões culturais que, naturalmente, possuem valores e efeitos independentes, mas a junção destas duas obras, trabalhando em complemento uma da outra, trazem outros resultados de interpretação. A música auxilia a narrativa, os personagens, a linguagem, as ações dramáticas em si. Os artifícios do universo dos sons são intrínsecos. A trilha sonora de um filme pode gerar significados ou despertar os significados já existentes e latentes no espectador. O efeito que a música surte na sua atuação como linguagem tem o poder de transmover a alma do espectador e fazê-lo vivenciar o drama na ficção. Temos então "a impressão da realidade, fenômeno de muitas consequências estéticas, mas cujos fundamentos são sobretudo psicológicos" (METZ, 2004, p. 17). A música aparece no processo de criação fílmica com toda sua presença em diferentes momentos com acepções tão diversas quanto as interpretações de quem assiste ao filme. Por isso, podemos considerar esta linguagem como ambígua e sujeita a diferentes leituras, mas que se complementa e constrói significados ao se unir aos demais recursos da cinematografia. A linguagem musical se funde a esses mecanismos, tecendo uma malha de componentes que formam o todo do filme.

\section{As Músicas do Filme Primo Basílio}

No filme estudado, identificamos momentos de superioridade que a linguagem da música assume. Uma linguagem saciando outras linguagens em forma de intersecção. Falamos outras linguagens incluindo a câmera, o cenário, os personagens, o figurino, elementos que também assumem formas de comunicar. No filme, a linguagem da trilha sonora complementa, é complementada e se mostra como elemento impulsor da criação cinematográfica. Cada nota musical é minuciosamente analisada para essa intersecção. A esse respeito, o responsável pela trilha sonora do filme Primo 
Basílio, Guto Graça, complementa em um dos depoimentos que fez para o making of da realização do filme. "Essa trilha do filme ela foi toda pré-programada usando samples de orquestra. Foi toda gravada assim. São 21 músicos de cordas e a gente tá dobrando, então, quer dizer, fora a orquestra que já foi pré-gravada, são mais 42 músicos, na realidade, que estão tocando". O artista ainda assume que foi um trabalho difícil, por ser clássico, mas extremamente bonito e delicado.

Assim, a trilha sonora, composta de letra ou não, pode ser considerada como uma corrente semiótica, um signo em cadeia que dá continuidade à trama, viabilizando a comunicação fílmica e assessorando o processo de tradução. Além da sonoridade orquestral, temos duas músicas marcantes que conseguem narrar parte da história do filme em forma de melodia. Duas músicas em momentos diferentes e pontuais da trama. $\mathrm{Na}$ primeira, Léau a La Bouche, que embala a dança de Luísa e Basílio, a música manifesta-se significativamente, contribuindo para a atmosfera erótica criada entre os primos. A respeito da atuação da música na linguagem fílmica, temos a observar:

Talvez a única definição suficientemente justa para a função da música no cinema, é de que, de uma maneira ou de outra, ela existe para 'tocar' as pessoas. 'Tocar' pode ser emocionar, arrancar lágrimas, causar tensão, desconforto, incomodar, narrar um acontecimento [...]. Ela está lá por algum motivo, e ainda que não ouçamos podemos senti-la. (BERCHMANS, 2006, p. 20)

A música deve ir ao encontro das diligências e necessidades do conflito da narrativa fílmica e da interação dos personagens envolvidos. Ela é um modo repentino de atingir as pessoas emotivamente. A persuasão que a música opera sobre as pessoas é forte e está vinculada diretamente à sua autonomia como forma de comunicação. A música, por si só, já possui um poder significativo de comunicação emocional. O cinema é arte que depende de uma criação coletiva, mas depende de outros recursos, utiliza-se de mais significados e, com isso, carece de outros elementos, tais como a música, o cenário, o vestuário. É certo que a forma como o cinema demanda um elemento musical é diversificada em função de estilo, época, linguagem, 
história, entre outros. No entanto, geralmente o cinema precisa da música como tem a necessidade da direção de arte, da fotografia, dos atores, da cenografia.

A música "L'eau à La Bouche" (1960), de Serge Gainsbourg, ilustra a situação entre Basílio e Luísa, naquele momento. Ela exerce função auxiliar na criação dramática, contribuindo para a cadeia semiótica engendrada por esse recurso fílmico:

\begin{tabular}{|c|c|}
\hline L'eau à La Bouche & Água na Boca \\
\hline Écoute ma voix écoute ma priére & Escute minha voz, escute minha súplica \\
\hline Écoute mon coeur qui bat laisse-toi faire & Escute meu coração que bate, não resista \\
\hline Jê t'en pris ne sois pas farouche & Eu te peço, não seja esquiva \\
\hline Quand me viens l'eau à labouche & Quando me vem a água à boca \\
\hline Je te veux confidante je te sens captive & Eu te quero confiante e te sinto presa \\
\hline Jê te veux docile jê te sens craintive & Eu te quero dócil e te sinto temerosa \\
\hline Jê t'em prie ne sois pás farouche & Eu te peço, não seja esquiva \\
\hline Quand me viens l'eau à labouche & Quando me vem a água à boca \\
\hline Laisse toi au gré du courant & Deixe-se ao sabor da corrente \\
\hline Porter dans Le lit Du torrent & Levar no leito da torrente \\
\hline Et dans le mien & E nо теи \\
\hline Si tu veux bien & Se você quiser \\
\hline Quittons la rive & Deixemos a margem \\
\hline Partons à la derive & Vamos partir à deriva \\
\hline Jê te prendais doucement et sans contrainte & Eu te tomarei docemente e sem pressão \\
\hline $\begin{array}{l}\text { De quoi as-tu peur allons n'aie nulle } \\
\text { crainte }\end{array}$ & $\begin{array}{l}\text { De que você tem medo? Vamos, não tenha } \\
\text { nenhum receio }\end{array}$ \\
\hline Jê t'em prie ne sois pas farouche & Eu te peço, não seja esquiva \\
\hline Quand me viens l'eau à labouche & Quando me vem a água à boca \\
\hline Oui jê serai calme jê saurai t'attendre & Esta noite junto de mim você virá se \\
\hline Cette nuit près de moi tu viendras 'átendre & estender \\
\hline Oui je serai calme jê saurai t'attendre & Sim, eu estarei calmo e saberei te esperar \\
\hline Et pour que tu ne t'effarouches & E pra que você não tenha medo \\
\hline Vois jê ne prend que ta bouche. ${ }^{1}$ & Veja, eu não prenderei tua boca. \\
\hline
\end{tabular}

Tradução nossa. 
Percebemos que o título da música, Água na Boca, já anuncia o desejo de Basílio por Luísa. Quando na letra temos: "Escute minha voz, escute minha súplica/ Escute meu coração que bate, não resista...”, é como se Basillio dissesse essas palavras à Luísa, tentando fazê-la ceder à sedução. "Eu te quero dócil e te sinto temerosa. De que você tem medo? "Vamos, não tenha nenhum receio": nesse trecho da música Basílio estaria solicitando a confiança da prima, revelando que ele percebia seus receios e tentando arrancar-lhe os medos. Vemos aqui "a tradução com amplitude quando o autor continua aos olhos do tradutor para que este não se perca, mas não segue as palavras tão estritamente, senão o sentido" (SANT'ANA, 2006, p. 18). Mesmo porque o filme é brasileiro e transmitido, originalmente, em língua portuguesa. Não se entende, ao certo, o que a letra da música diz, mas o tecido de significados que se forma nessa cena conduz ao sentido original.

Embora a música esteja em francês e dificilmente teríamos prestado atenção ao conteúdo da letra, mesmo porque ela não é tocada integralmente, podemos sentir a música e ajustá-la à cena exibida. Não deixamos de considerar que a música caracteriza-se como um todo composto por letra e melodia. O erotismo vem não só da letra, mas da melodia também e essa combinação alcança o efeito. "No processo de criação, o criador caminha do caos para a ordem. A música, deste modo, serve de auxílio nessa busca pelo cosmos, pela ordem" (SALLES, 1990, p. 138).

A trilha sonora do filme, elaborada por Guto Graça Melo, também foi baseada nas músicas dos anos 1950/1960, incluindo, além da L'ean a La Bouche, as músicas de Bossa Nova Saudades do Brasil, de Antônio Carlos Jobim e Apelo, de Vinícius de Moraes. O movimento Bossa Nova ficou associado ao crescimento urbano brasileiro - impulsionado pela fase de desenvolvimento da presidência de Juscelino Kubitschek (1955-1960) - pois se iniciou, segundo muitos críticos, quando foi lançado, em agosto de 1958, ano em que se passa a história do filme, um compacto simples do violonista baiano João Gilberto (considerado o papa do movimento), contendo as canções Chega de Saudade (Tom Jobim e Vinícius de Moraes) e Bim Bom (do próprio cantor). O termo "bossa" era uma gíria carioca que, no fim dos anos cinquenta, significava 'jeito', 'maneira', 'modo'. Quando alguém fazia algo de modo diferente, original, de maneira fácil e simples, dizia-se que esse alguém tinha 'bossa'. Em vários momentos do filme, a trilha sonora se 
manifesta sempre de forma significativa. Algumas vezes para provocar suspense, outras para instigar a curiosidade e inferir sentidos no espectador e outras, ainda, para ajudar a contar a história transmutada como é o caso da música francesa analisada acima e a canção Apelo. A música surge, nesses momentos, como componente impulsor da criação de uma forma geral. A música que segue foi escolhida para finalizar o filme com emotividade. Ela é tocada durante as últimas filmagens da trama:

\section{Apelo}

Ah! Meu amor não vás embora

vê a vida como chora

Vê que triste esta canção

Não eu te peço não te ausentes

pois a dor que agora sentes

Só se esquece no perdão

Ah! Meu amado me perdoa

pois embora ainda te doa

A tristeza que causei

Eu te suplico não destruas

tantas coisas que são tuas

Por um mal que já paguei

Ah! Meu amado se soubesses

da tristeza que há nas preces

Que chorar te faço eu

Se tu soubesses do momento

quanto ao arrependimento

Como tudo entristeceu

Se tu soubesses como é triste

eu saber que tu partistes

Sem sequer dizer adeus 


\section{Ah! meu amor tu voltarias \\ e de novo cairias \\ A chorar nos braços meus}

Nas vozes de Dick Farney e Claudete Soares, a música é cantada como se fosse um diálogo entre Jorge e a esposa. Quando, na $1^{\mathrm{a}}$ estrofe, o cantor diz: "Ah! meu amor não vás embora, vê a vida como chora, vê que triste essa canção", sugere que Jorge dizia essas palavras a Luísa quando ela agonizava, momentos antes de sua morte. Já em seguida, na segunda estrofe, Claudete Soares toma as palavras cantando: "Ah! Meu amado me perdoa, pois embora ainda te doa a tristeza que causei...". Esse trecho é cantado como se fossem as palavras de Luísa, lamentando e pedindo perdão ao marido. No próximo trecho: "Eu te suplico não destruas tantas coisas que são tuas por um mal que já paguei”, o cantor retoma a música como se fosse Jorge implorando que Luísa fosse forte, que suportasse, ou seja, que não destruísse a vida, as coisas que eram dela, ele já tinha pago pelo mal da esposa, com o sofrimento, devido à traição e a doença dela.

$\mathrm{Na}$ próxima estrofe, a cantora retoma as palavras: "Ah meu amado se soubesses da tristeza que há nas preces que chorar te faço eu. Se tu soubesses do momento quanto ao arrependimento, como tudo entristeceu." Estas palavras seriam atribuídas à Luísa, desabafando a tristeza que sentia, bem como todo o arrependimento por ter traído o marido. Nas últimas estrofes da música, Dick Farney canta: "Se tu soubesses como é triste eu saber que tu partiste sem sequer dizer adeus. Ah! Meu amor tu voltarias e de novo cairias a chorar nos braços meus". Esse último trecho remete às palavras de Jorge, como se ele falasse à Luísa, já morta, que se ela soubesse da tristeza e revolta do marido em relação à sua morte, voltaria para viver com ele.

No processo criativo do cinema, a trilha sonora se apresenta como inspiradora e tem o poder de tocar o espectador, mexer com as emoções. Ela é parte de um processo que desencadeia outro processo, isto é, o da criação cinematográfica. A trilha sonora cria o clima que o diretor busca para a criação, climas de tensão, de paixão, de melancolia, que compõem os diferentes momentos de clímax do filme. Notamos que as músicas analisadas acima ilustram "um processo de associação por contiguidade com um elemento comum de similaridade" (PIGNATARI, 1979, p. 37) - a mensagem 
principal das letras que conduzem ao texto original, mesmo que de forma diferente do código de origem.

Assim, a música deve ir ao encontro do conflito da história e da interrelação dos personagens e, ao assistir ao filme, percebemos que ela conduz os movimentos dos personagens transmitindo ao espectador o clima de paixão e sedução, no caso da música L'eau a La Bouche, e de desespero e dor, além do arrependimento, no dueto da música Apelo. Os efeitos proporcionados pela melodia funcionam como elemento de elo entre os personagens, como também entre o espectador e a história. Segundo Salles (1990), existe uma transição do mundo da criação para o mundo criado (o da ficção) cruzando o mundo real do artista, que neste caso é o diretor, isto é, realidade e ficção que se confundem ou se complementam de forma que a música seja trabalhada no âmbito da simbologia, da significação.

Enquanto a música é cantada, ao final do filme investigado, a câmera filma a imagem da casa de Jorge e Luísa, que vai se modificando no decorrer da canção. No início da música, a casa é filmada em sua imagem original, como no início do filme. A câmera focaliza a imagem em ângulo centralizado, dando a ideia do começo da história, quando a vida do casal ainda estava estabilizada. Na sequência da filmagem, percebemos que a imagem da casa vai, gradativamente, perdendo a cor, como se fosse ficando envelhecida, sugerindo que aquela casa já fazia parte do passado, de um tempo que não voltaria mais. Enquanto a música Apelo é tocada, a câmera, num traveling para trás, vai se afastando da casa e ela se torna, paulatinamente, como uma foto envelhecida, dando a ideia de tristeza, de passado, de uma época feliz que seria impossível de ser reconstituída. E, já no final da música, a câmera se afasta mais da imagem centralizada e vemo-la praticamente irreconhecível, como se o tempo tivesse apagado a história de um casamento estável. A filmagem da casa torna-se, agora, uma simples fotografia envelhecida, aparentemente danificada pelo tempo e, ao fundo, um plano escuro insinua a tristeza, a escuridão e uma época irrecuperável.

Nessas cenas finais, temos a combinação de um elemento visual com um sonoro, que pôde traduzir o desfecho infeliz da trama, ilustrando o sincretismo da linguagem cinematográfica, que funde elementos diversos numa única tomada, mostrando assim seu poder de recriação, reinvenção. A linguagem musical nas últimas cenas é fundamental para um final que atua 
como propulsor de emoções no espectador. A intersecção dos elementos imagem e som recria e reconta a história de forma melancólica, fazendo com que vivenciemos o filme como um todo, em seus últimos momentos. Por isso também que a música toda ${ }^{2}$ foi tocada em dueto e expressivamente. No texto original, o final do romance se estende um pouco mais descrevendo o destino de Jorge após a morte da esposa e outros detalhes. Certamente, o diretor terminou sua história nesse ponto para maior dramaticidade e síntese. A música escolhida para os últimos minutos da trama reconstitui a narrativa na linguagem musical, trabalhando a intertextualidade em relação ao texto original.

Segundo Berchmans (2006, p. 20-35) não há parâmetros específicos para aplicar a música ao cinema. Ela colabora substancialmente com o filme de forma dinâmica e instigante. Isso ocorre porque, desde o início da montagem do filme, muitos profissionais interferem criativamente no que vai ser o longa-metragem após a edição. O roteirista, o diretor, o produtor, o editor de som, algum ator, todos, de uma forma ou de outra, contribuem para o resultado final que a música alcança em um filme. Vimos, por meio da análise das músicas acima, que elas são tocadas em pontos cruciais da narrativa, os quais foram escolhidos com cuidado para que o espectador fosse atingido emocionalmente e para trazer às telas, na sua essência, a narrativa de Eça de Queirós. Ademais, identificamos que o objetivo do diretor e produtor, Daniel Filho, também foi atingido. Em um dos depoimentos que deu nas gravações do making of da trama ele revela que seu intuito era transmitir uma história de amor, de paixão, porque acha que essas histórias são eternas.

O amor, ele é calmo, ele é carinhoso, ele abriga e a paixão, queima, desespera, é sensual, mais do que sensual, é sexual. Quando uma história consegue atravessar anos e anos éporque está falando do sentimento e sentimento não tem época.

Outra preocupação do diretor era quanto à fidedignidade da obra ao texto queirosiano e com as escolhas que fez durante a transmutação, ele considera que a essência dessa fidelidade foi mantida:

${ }^{2}$ O dueto aplicado na música Apelo resume a tragédia que deu o desfecho ao filme. A música é tocada do começo ao fim para surtir este efeito. 
O filme é absolutamente fiel ao livro do Eça de Queirós. Logicamente, pra se contar em uma hora e pouco, quase duas horas. Não dá para se contar o livro todo. Alguns personagens fantásticos foram simplesmente eliminados da história porque pertenciam a outras histórias paralelas à história central do drama como chamou, aliás, Eça de Queirós, um drama familiar [...] tenho certeza de que me mantive fiel ao Eça. Consegui fazer o que eu queria a princípio, faz̧er uma bistória de amor, paixão.

Considerando a contribuição da música para a realização do objetivo do diretor, percebemos que ela auxilia na síntese da história em sua mais pura essência. Por meio das letras e melodias analisadas aqui, vemos que em poucos minutos páginas e páginas queirosianas são sintetizadas e transmitidas ao espectador por meio da elipse cinematográfica.

A música exerce um papel psicológico e de linguagem que atua como ferramenta dramática, amplamente utilizada por diretores. Ela tem a força de manipular a reação emocional do espectador. Por meio da música, procurase elevar a experiência do receptor, sensibilizar imoderadamente, tentar transmutar a história dos personagens numa experiência inesquecível e impactante. Por isso também dizemos que esse recurso no cinema é um componente utilizado em função da imagem e da tradução. Para esse respeito, ao voltarmos à nossa análise, qual seria o efeito de L'eau a La Bouche se ela não tivesse sido tocada no momento em que Basílio e Luísa dançavam? Ou mesmo, a música Apelo não provocaria a comoção que provocou se não estivesse interceptada à imagem da casa de Jorge e Luísa que se desalenta a cada nota musical, a cada verso cantado. Atestamos essas afirmações com um depoimento dado pelo diretor Robert Grieve aos autores Seger e Whetmore para a obra Do Roteiro para a Tela:

Ao escolher os sons, tento pensar em algo que acrescente um tom psicológico à história sem chamar muita atenção para si mesmo. Devemos operar num nível subliminar e realçar a atmosfera que o diretor e o roteiro determinam (SEGER; WETHMORE, 2009, p. 201). 
Assim, ao ouvir a trilha sonora do filme Primo Basilio, em especial as músicas aqui analisadas, percebemos que ela foi essencial. $O$ filme basicamente se apoia sobre ela. Além das músicas com letras e melodia, percebemos sons unitários que significam algo em algum momento. Por exemplo, o som da buzina na porta da casa de Luísa quando ela esperava ansiosamente pelo primo. Este som foi utilizado somente para instigar o espectador a pensar que finalmente Basílio chegara, no entanto isso não acontecera. Vemos o desespero de Luísa a olhar pela janela e seu ar de decepção ao perceber que a buzina era de outro carro qualquer, não de seu primo. Enfim, destacamos que, no filme, imagem e som caminham interseccionados, uma baseando-se no outro, comprovando a ideia da cadeia semiótica contínua que se estabelece em forma de rede na criação cinematográfica, pois

a impressão de realidade que o filme nos dá não se deve de forma alguma à forte presença do ator, mas sim ao frágil grau de existência destas criaturas fantasmagóricas que se movem na tela incapazes de resistir à nossa constante tentação de investi-las de uma 'realidade' que é a da ficção (noção de 'diegese'), de uma realidade que provém de nós mesmos, das projeções e identificações misturadas à nossa percepção do filme (METZ, 2004, p. 23).

No filme Primo Basílio, a linguagem da música é transportada para a linguagem audiovisual. O resultado dessa transmutação de linguagens se concretiza no produto final e coloca essa forma de comunicar que a música exerce no papel de semiose no processo criativo do cinema, reproduzindo a realidade mesmo que ela tenha se originado de uma obra fictícia escrita no século XIX.

\section{As Músicas no Roteiro Filmado: uma revelação}

A música como linguagem atua substancialmente na recriação cinematográfica. Porém para que se atinja o efeito desejado é preciso elencar as melhores possibilidades, analisar as opções, renunciar algumas preferências, fazer trocas e escolhas que trarão maior verossimilhança à cena. Conforme revelado no início desse trabalho, tivemos acesso a um documento inédito 
que somente a produção do filme possuía e que foi disponibilizado para este estudo: o roteiro filmado.

Antes de partirmos para a análise desse documento e revelar o que foi descoberto em relação às escolhas das músicas atuantes na trama, é importante que façamos um apanhado sobre a teoria desse elemento indispensável para a realização de um filme. Os "rastros" da criação possibilitam acompanhar, por meio de documentos de criação, grande parte do andamento da obra desde seu início até o seu, podemos dizer, "primeiro final". ${ }^{3}$ É por meio desses passos que identificamos, por exemplo, um corte de cena, uma edição de filmagem, uma mudança de diálogo ou de qualquer outro gênero de texto dentro do roteiro, enfim, o devir da obra cinematográfica.

Em se tratando de roteiro fílmico, Field (2001, p. 2) o define como uma "história contada em imagens, diálogos e descrições, localizada no contexto da estrutura dramática." É por meio dele que o criador estrutura, "esqueleta", projeta o seu trabalho, dando vida à narrativa contada em tempo real. Temos a história como um todo, composta por suas partes (ação, personagens, cenas, sequências, etc.) que pode ser lapidada pelo roteirista e/ ou diretor.

No que diz respeito ao roteiro de uma obra recriada, "adaptar uma história tirada de outra fonte em geral exige mais habilidade e maior compreensão do veículo cinematográfico do que criar uma história nova" (HOWARD; MARBLEY, 1996, p. 36). Nem tudo pode ser transmutado, somente aquilo que vai instigar, envolver, prender a atenção do receptor é que será viável adaptar. Encontrarmos, assim, o poder da música no quesito emocionar, reter o receptor, embalar por meio dos recursos sonoros, sintetizar os acontecimentos. Na tradução intersemiótica deve-se ter a consciência de até onde se pode e se deve cumprir com a fidedignidade da obra original.

\footnotetext{
3 Dizemos primeiro final calcadas nos pressupostos da Crítica Genética contemporânea que colocam a obra de arte como um "gesto inacabado", podendo ser recriada quantas vezes forem a quantidade de recriadores. Exemplo disso está no filme em estudo: o primeiro texto foi uma obra literária de um autor português, a segunda (re)criação foi uma adaptação desse texto para uma minissérie televisiva e, agora, nos deparamos com uma terceira versão da mesma obra, desta vez, na forma de um filme.
} 
"Se a tradução é uma forma, a traduzibilidade deve ser essencial a certas obras" (BENJAMIN, 2008, p. 67).

Acontecimentos que demoram anos, meses, em um romance, se tornam bem mais interessantes ao ocorrerem em um mesmo dia, em um filme. Ao recriar uma obra, por meio da transmutação, é importante que se tenha um constante contrabalanço entre a fidedignidade à primeira versão e a necessidade do drama, da intensidade e compreensão da nova releitura que nasce:

Quando você adapta um livro ou romance em roteiro tem que considerá-lo um roteiro original, baseado em outro material. Você não pode adaptar literalmente um romance e fazê-lo funcionar [...]. Quando você adapta um livro em roteiro, tudo o que precisa usar são os personagens, eliminar outros, criar novos incidentes ou eventos, talvez alterar a estrutura inteira do livro (FIELD, 2001, p. 151).

O roteiro, seja ele o próprio texto na sua "primeira versão" ou inspirado, ao ser transcodificado de outra fonte, deve ser representado na tela como algo real para o espectador. Lembramos que uma das características principais do cinema é a sensação da veracidade. "Os atores são os personagens, os lugares e fatos parecem tão reais quanto o cineasta consegue fazê-los reais" (HOWARD; MARBLEY, 1996, p. 38). Dentro de tais considerações, traçamos a pertinência de analisar parte do roteiro como um dos documentos do processo criativo nesta arte coletiva (cinema) e mostrar como se deu a escolha das músicas constituintes da trilha sonora. Ele, o roteiro, pode ser considerado o elemento que dá início à trama; a "espinha dorsal" de todo o conflito e resolução que estão por vir; o vir a ser da arte que tocará as emoções dos mais diversos indivíduos. Em um dos trechos do referido documento, mais especificamente na tomada quarenta e um das cenas, descobrimos que as primeiras opções para a música a ser tocada durante a dança entre Basílio e Luísa não era L'eau a La Bouche, como podemos mostrar no seguinte trecho do documento: 
INT. CASA DE JORGE/SALA - DIA 41 ${ }^{[4]}$

DEDOS NOS COMANDOS DE UMA VITROLA. UM DISCO CAI E COMEÇA A TOCAR. PATRICIA (PEREZ PRADO) OU LUNA ROSSA (TEDDY RENO).

\section{BASÍLIO}

\section{(ESTENDENDO-LHE A MÃO)}

Esse foi o maior sucesso do verão em Saint-Tropez... Vem cá

\section{LUÍSA (RELUTANTE)}

Tempo que eu não danço. Desde a noite do meu casamento...(SE TOCA)

nossa...!

\section{BASÍLIO (ENLAÇANDO-A PELA CINTURA)}

É só se deixar levar.

ELES COMEÇAM A DANÇAR, MAS LUÍSA SE ATRAPALHA.

\section{LUÍSA}

Viu como sou ruim?

\section{BASÍLIO}

Duvido. Tire os sapatos.

\section{LUÍSA}

Ahã?

\section{BASÍLIO}

Os sapatos. Tire-os

\section{LUÍSA OBEDECE.}

\section{BASÍLIO}

Coloque seus pés em cima dos meus.

LUÍSA FAZ O QUE ELE MANDA E, COM OS PÉS EM CIMA DOS PÉS DELE,SE DEIXA LEVAR. E SE ENTREGAM À SENSUALIDADE DA DANÇA. A MÚSICA ACABA E ELES CONTINUAM GRUDADOS, BALANÇANDO. BASÍLIO COCHICHA NO OUVIDO DELA:

${ }^{4}$ O fragmento do roteiro está exatamente como recebemos. Preferimos colocá-lo em sua forma original para oferecer maior autenticidade. 


\section{BASÍLIO (CONT’D)}

Sabes que eu nunca consegui te esquecer?

LUÍSA

Conversa.

\section{BASÍlIO PÁRA DE 'DANÇAR', OLHA-A NO OLHOS E DÁ-LHE UM BEIJO NA BOCA. ELA TENTA RESISTIR. ELE CONTINUA E ELA LHE DÁ UM TAPA NO ROSTO.}

Percebemos, portanto, que a canção francesa não estava prevista. Havia duas alternativas de músicas para esta sequência e nenhuma foi utilizada. A música Patrícia, de Perez Prado, apresenta um ritmo mais acelerado, e não traria a mesma volúpia pretendida. Além disso, por que utilizar uma canção com título feminino que não correspondia ao nome da protagonista? Já a música italiana Luna Rossa (Lua Vermelha), de Teddy Reno, até poderia estar concorde com a circunstância, mas sua letra traz um sentimento de melancolia, de abandono e um ritmo bastante compassado, vagaroso, que não condiria com a tentativa de sedução de Basílio. Seria incoerente se fosse utilizada uma melodia que falasse de abandono, em uma situação em que a conquista é o que predomina. A música que não estava no roteiro, mas que foi selecionada para compor o filme traz uma mistura de ritmo moderado, um clima de sedução por meio dos movimentos embalados pela canção e palavras sedutoras que envolvem os personagens e embalam a cena e a quem a assiste. Os elementos constituintes da gênese cinematográfica operam a tradução de forma que sentidos e ressignificações sejam gerados e aceitos pelo espectador, pois

A contemporaneidade aponta o cinema como um processo técnico/ estético absorvedor de uma intrigante noção de imagem que não se sedimenta, uma vez que a representação hipermidiática de texto, imagem e som, numa cena fílmica, desdobra as (re)significações verbais e não-verbais (GARCIA, 2007, p. 174).

No que diz respeito à segunda música aqui analisada, apresentada no final do filme, em nenhum momento encontramos alguma sugestão de seu uso. Ao lermos o roteiro, na tomada duzentos e trinta e um (última cena) 
somente nos deparamos com a última fala de Basílio, comentando com um amigo sobre a morte da esposa, bem como a descrição de seus atos e gestos investindo em outras conquistas no cenário em que se passa a trama. Coincidentemente ou não, o mesmo cenário em que se deu o reencontro entre os primos: o Teatro Municipal de São Paulo. Nada mais é planejado na escrita no roteiro e não encontramos registros que nos levem a saber sobre o momento e o porquê da escolha da música Apelo.

Quanto às opções dessa trilha sonora, trabalhamos com hipóteses. Nossa investigação abarca uma arte coletiva e muitas decisões podem ter sido tomadas sem deixar "rastros". Por mais documentos de processo que tenhamos ao alcance, por mais dados que os criadores nos concedam, não significa que possamos conhecer, na íntegra, o processo. Qualquer informe, qualquer registro e cada relação estabelecida nos inteira um pouco mais desse fenômeno consistente e complexo. Esses constantes ajustes - substituições, cortes, acréscimos, remoções - geradores de construção, não seguem uma linearidade. Não sabemos em qual momento tais alterações foram feitas e a ordem em que se estabeleceram. Isso significa que esses experimentos podem conter idas e vindas, o que permite ao artista, muitas vezes, fazer a mudança ou preservar formas anteriores que, em algum momento, podem ser retomadas. Quando tentamos seguir o percurso e estipular relações entre as mutações, nos defrontamos com a ação do criador e suas decisões, buscando entender, dessa forma, os motivos que o conduzem. Em virtude de todas essas considerações reiteramos a atuação da trilha sonora, mais especificamente das músicas no processo de recriação no cinema.

\section{Considerações Finais}

O estudo da música como um dos elementos necessários para a reconstrução de uma obra fílmica mostrou a importante e potente atuação desse elemento no processo recriativo de uma obra cinematográfica. Apoiados pelos estudos da tradução e utilizando a Crítica Genética como metodologia, vimos que as transformações sucedidas na transmutação de um código a outro são reveladas por meio da análise de documentos de processo (roteiro) e a investigação dos elementos que compõem a trama audiovisual (para aqui, a música). 
Mostramos que o filme não foi uma mera ilustração do texto queirosiano, embora tenha mantido a essência da mensagem do escritor português. Nesse sentido afirmamos que a transmutação, consoante à sua essência, não tem como objetivo simplesmente copiar o original, já que este pode se mostrar como variável, versátil, instável e que a música tem o potencial de auxiliar nesse exercício de análise e síntese, necessário para uma tradução/ recriação.

Quando propusemos a análise da música na adaptação fílmica da obra literária O Primo Basílio, de Eça de Queirós, a intenção foi mostrar a atuação desse elemento da trilha sonora no diálogo entre as linguagens literária e fílmica, tentando percorrer o caminho traçado pela coletividade dos profissionais do cinema para fazer com que esse longa-metragem chegasse ao público, ou seja, investigar parte do processo criativo da obra como método para enunciar como funciona a tradução de um produto ao outro.

Para tanto, utilizamo-nos da análise das músicas utilizadas no filme, bem como o documento físico do processo (o roteiro filmado). Vimos que a trilha sonora é mais que um simples elemento constituinte, sendo geradora de ressignificações dentro de uma trama cinematográfica. Ademais, revelamos, por meio do estudo do roteiro fornecido pela assessoria da produção/ direção do filme, as escolhas prévias de uma das músicas tocadas em um momento crucial da história, além de nos depararmos com o não planejamento, por escrito, da música que dá desfecho à obra. Enfim, corroboramos que os estudos sobre a criação cinematográfica, cada vez mais explorados, podem contar com diversos recursos e documentos para a auxiliar a investigação.

\section{Referências}

BENJAMIN, W. A Tarefa do tradutor. Revista Humboldt, Munique, n. 40, p. 38-44, 2008.

BERCHMANS, T. A música do filme: tudo o que você gostaria de saber sobre a música de cinema. São Paulo: Escrituras, 2006. 
CHION, M. A audiovisão. Lisboa: Edições, Texto e Grafia, 2011.

DANIEL FILHO. Primo Basilio. [Filme-vídeo]. Coprodução de Globo Filmes, Lereby Produções, Miravista, Total Entertainment, direção de Daniel Filho. São Paulo, Globofilmes, 2007. 134 min. color. son.

FIELD, S. Manual do roteiro. Tradução de Screenplay. Rio de Janeiro: Objetiva, 2001.

GARCIA, W. Prospero's Book - da literatura ao cinema. Olhar, São Carlos, a. 9, n. 16, jan./jul. 2007.

HOWARD, D.; MABLEY, E. Teoria e prática do roteiro. Tradução Beth Vieira. São Paulo: Globo, 1996.

JAKOBSON, R. Lingüistica. Poética. Cinema. 2. ed. Tradução Haroldo de Campos. São Paulo: Perspectiva, 2007.

METZ, C. A significação no cinema. Tradução Jean-Claude Bernadet. São Paulo: Perspectiva, 2004.

PANICHI, E. R. P.; CONTANI, M. L. Pedro Nava e a construção do texto. Londrina: Eduel; São Paulo: Ateliê, 2003.

PIGNATARI, D. Semiótica e literatura: icônico e verbal, oriente, ocidente. São Paulo: Cortez \& Moraes, 1979.

QUEIRÓS, E. de. O primo Basílio. Porto; Braga: Ernesto Chardron, 1878.

SALLES, C. A. Criação em processo: Ignácio de Loyola Brandão e Não verás país nenhum. 1990. Tese (Doutorado em Linguística Aplicada e Estudos da Linguagem) - Pontifícia Universidade Católica de São Paulo, São Paulo.

SANT’ANA, A. R. de. Paródia, paráfrase \&o cia. 7. ed. São Paulo: Ática, 2006.

SCHAFER, R. M. A afinação do mundo. Tradução Marisa Trench Fonterrada. São Paulo: Editora UNESP, 2001. 
SEGER, L.; WHETMORE, E. J. Do roteiro para a tela. Tradução Sueli da Silva Saraiva. São Paulo: Bossa Nova, 2009.

SOUZA, J. B. G. Procedimentos de trabalho na captação de som direto nos longametragens brasileiros Contra todos e Antônia: a técnica e o espaço criativo. 2010. Tese (Doutorado em Ciências da Comunicação) - Universidade de São Paulo, São Paulo.

SHUN, L. R. O áudio não-linear na hipermídia. 2008. Tese (Doutorado em Comunicação Semiótica) - Pontifícia Universidade Católica de São Paulo, São Paulo.

Enviado em: 06/10/2016

Aceito em: 11/11/2016 